\title{
Mammals of the Bodoquena Mountains, southwestern Brazil: an ecological and conservation analysis
}

\author{
Nilton C. Cáceres ${ }^{\text {; }}$ Marcos R. Bornschein ${ }^{2}$; Wellington H. Lopes ${ }^{1}$ \& Alexandre R. Percequillo ${ }^{3}$ \\ ${ }^{1}$ Departamento de Biologia, CCNE, Universidade Federal de Santa Maria. Faixa de Camobi, km 9, 97110-970 Santa Maria, \\ Rio Grande do Sul, Brasil. \\ 2 Liga Ambiental. Rua Olga de Araújo Espíndola 1380, bloco N, ap. 31, 81050-280 Curitiba, Paraná, Brasil. \\ 3 Departamento de Ciências Biológicas, Escola Superior de Agricultura "Luiz de Queiroz", Universidade de São Paulo. \\ Avenida Pádua Dias 11, Caixa Postal 9, 13418-900 Piracicaba, São Paulo, Brasil.
}

\begin{abstract}
We carried out a mammalian survey in the neighborhoods of the Serra da Bodoquena National Park, Mato Grosso do Sul state, a region poorly known in southwestern Brazil. During the months of April, May and July 2002 we used wire live trap, direct observation, indirect evidence (e.g. tracks), carcasses, and interviews with local residents to record mammalian species. Fifty six mammal species were recorded, including threatened species (14\%). These records were discussed regarding species abundance, distribution, range extension, habitat, and conservation. The geographic distribution and ecology of the poorly known marsupials Thylamys macrurus and Micoureus constantiae in Brazil are emphasized.
\end{abstract}

KEY WORDS. Brazilian savanna; deciduous forest; distribution; Mammalia; species richness.

RESUMO. Mamíferos da Serra da Bodoquena, sudoeste do Brasil: uma análise ecológica e conservacionista. Efetuamos um levantamento de espécies de mamíferos no entorno do Parque Nacional da Serra da Bodoquena, Estado de Mato Grosso do Sul, uma região pouco conhecida no sudoeste do Brasil. Durante os meses de abril, maio e julho de 2002 efetuamos captura com armadilhas, observação direta, busca por evidências indiretas (e.g. pegadas), carcaças, e entrevistas com moradores locais para registrar espécies de mamíferos. Cinqüenta e seis espécies foram registradas, incluindo ameaçadas de extinção (14\%). Discutimos abundância, distribuição geográfica, preferência de habitat e conservação das espécies registradas. A distribuição geográfica e ecologia dos marsupiais Thylamys macrurus e Micoureus constantiae no Brasil são enfatizadas.

PALAVRAS-CHAVE. Cerrado; distribuição; floresta decidual; Mammalia; riqueza de espécies.

Neotropical mammals are a diverse group encompassing hundreds of species mainly distributed in the Orders Rodentia, Didelphimorphia, Chiroptera, Primates and Carnivora (Emmons \& FeER 1997). The three first groups comprehend more than $50 \%$ of all Neotropical species, and little is known on their geographic distribution and biology in several sub-regions. Mato Grosso do Sul is a Brazilian state poorly known on its mammalian fauna, particularly the small mammal fauna (EISENBERG \& REDFORD 1999). It is located in the southwestern Brazil and is important due to presence of a variety of vegetation types, such as the Pantanal marshlands, the Cerrado savannas, and the deciduous and semideciduous forests (Aв'SABER 1988, IbGE 1992).

The Bodoquena Mountains, with more than $100 \mathrm{~km}$ of extension in north-south orientation, are a relevant massif in the western Brazil, being limited by the floodplains of Pantanal at west and north, by the Maracaju Mountains (Cerrado biome) at east, and by the Cerrado-Chaco transition at south, in the vicinities of Paraguay (Ibge 1992). The vegetation in the region is mainly composed by deciduous forest, but portions of semideciduous forest and Cerrado occur as well, this latter mainly occurring in the peripheral areas. The deciduous forest is composed by floristic elements mainly from the Atlantic rainforest domain (IbGe 1992, Damasceno-JúnIOR et al. 2000). So, this massif of Bodoquena can reveal a peculiar mammalian fauna, since it is surrounded by regions of distinct mammal composition, such as the Cerrado, Pantanal, Chaco, and the Amazon and Atlantic forests (IbGe 1992, EISENBERg \& REDFORD 1999).

The Mato Grosso do Sul state, and mainly the Bodoquena Mountains, are only roughly known on autochthonous faunal composition. The few mammalian surveys carried out in this region were mainly concentrated in the Pantanal flood plains at Corumbá municipality (e.g. SCHALler 1983, AlHo et al. 1987, MaURo \& CAMpos 2000). The small mammal species known for that region in southwestern Brazil are rather regionally distributed taxa such as some sigmodontinae and echimyidae rodents, didelphid marsupials and bat species. However, the knowledge

Revista Brasileira de Zoologia 24 (2): 426-435, junho 2007 
of small mammals, as well as median and large-sized mammals, in the Mato Grosso do Sul state is still limited (EISENBERG \& REDFORD 1999). The species richness expected for the southwestern Brazil is high, since this region, mainly composed by Cerrado, is upon the influence of several adjacent biomes (VIEIRA 1955, Streilen 1982, Fonseca et al. 1996, Emmons \& Feer 1997).

On a conservation view, the Mato Grosso do Sul state shows reasonable to non-disturbed areas of Cerrado in its western portion, adjacent to the Pantanal, just where Bodoquena Mountains are localized. However, highly disturbed areas of Cerrado are found in the east of the state, close to the frontiers of the São Paulo, Paraná, and Goiás states.

The mammalian survey in Bodoquena Mountains will provide advances to the knowledge of the distribution of mammals in the country and in the South America, as well as information for the conservation of the recently founded Serra da Bodoquena National Park (SBNP). This survey will also be the base for future investigations and management of this conservation unit, which still preserves part of the landscape of southwestern Brazil.

\section{MATERIAL AND METHODS}

\section{Study area}

The recently established (September 2000) SBNP comprises nearly 73.000 ha in extension and is drained by two river basins: Salobra river, which runs northward ending in the Miranda river, and Perdido river, which runs southward ending in the Apa river. Both basins are left bank tributaries of the Paraguay river. The SBNP comprises the main preserved areas of the Bodoquena Mountains (Bodoquena plateau), which is the Pantanal headwaters. More important, the SBNP comprises the main portions of the Decidual Seasonal Forest (Atlantic forest lato sensu) in the Mato Grosso do Sul state, due to its hilly and limestone characteristics (IBgE 1992, DAMASCENO-JúNIOR et al. 2000).

In relation to conservation and land use, the region of the Bodoquena Mountains is represented by two landscape uses: one at the eastern side of the SBNP, with altitudes around 350 to $700 \mathrm{~m}$, is dominated by livestock. It also embraces the south and north sides where livestock is replaced locally by agriculture or mining (DAMASCENo-JúnIOR et al. 2000). The other landscape use area is located in the western side comprehending the plains of the Pantanal not subject to seasonal flooding at 250 to $150 \mathrm{~m}$ in altitude. It also embraces a narrow, isolated area of mountains (Fecho dos Morros; 500 to $800 \mathrm{~m}$ ) at west (AB'SABER 1988). This second region holds a large indigenous reserve (Kadiweus, with nearly $530.000 \mathrm{ha}$ ) at northwest, and is extensively dominated by preserved cerradão (arboreal savanna), but with pasture lands at southwest. However, ecotourism has improved in the Bodoquena Mountains as a whole, and probably will be the main economic source of the region in the future.

Most of the surroundings of the SBNP were surveyed, except for the southwest part, where there was no access by road. Areas surveyed were near to roads, trails, bridges, and adjacent lands that outline the SBNP. For trapping the small mammal fauna, three areas were selected: 1) at the mid-west of the Bodoquena Mountains, namely Fazenda Princesinha, in the municipality of Bonito ( $21^{\circ} 05^{\prime} \mathrm{S}, 57^{\circ} 29^{\prime} \mathrm{W}, 550 \mathrm{~m}$ above sea level); 2) at northwest, Fazenda Califórnia at Bodoquena municipality $\left(20^{\circ} 42^{\prime} \mathrm{S}, 56^{\circ} 51^{\prime} \mathrm{W}, 470 \mathrm{~m}\right)$, and 3$)$ at northeast, near Fazenda Santa Terezinha, also at Bonito (20 50'S, 56 $\left.37^{\circ} \mathrm{W}, 615 \mathrm{~m}\right)$. Medium and large mammals were surveyed in additional areas located in the Jardim and Bela Vista municipalities and also along the roads MS 382 (20 km of extension; Baía das Garças westward), MS 339 (70 km; between Bodoquena city and Baía das Garças), MS 178 (110 km; between Bodoquena city and BR 267), BR 267 (18 km; between MS 178 and MS 472), municipality road from BR 267 to Perdido river (30 km), and MS 472 (30 km; BR 472 southward).

Several phytophysiognomies were sampled, including deciduous dry forest, semideciduous gallery forest, and Cerrado habitats, such as cerradão and cerrado stricto sensu, besides anthropic environments, such as peri-urban and road-sides where pastures were dominant. In general, cerradão and deciduous forest occurred in greater proportions in the sampled areas (see IвGE 1992): cerradão occupying the flatter relief areas, and deciduous forest slopes and top of mountains. Considering the conservational status, the cerradão has been the main target of deforestation for the settlement of pastures, since it occurs on flat areas. Thus, environments surveyed in this study were mainly disturbed primary forest or secondary vegetation areas locally known as capoeiras and capoeirões, but often connected to large patches of preserved vegetation.

\section{Mammalian survey}

The mammalian survey was carried out along three field seasons: one of six days long in April 2002 (Fazenda Princesinha region), other of five days long during May 2002 (Fazenda Califórnia region), and the last one of four days long in June 2002 (three days at Fazenda Santa Terezinha region and one day at Bonito to Bela Vista region).

During each field work, forest trails, roads, puddles, river and pond margins were scanned in search of mammals and their signs, such as tracks, feces and carcasses. Tracks were identified following BECKER \& DALPONTE (1999). In a typical field day, active search for mammalian evidence started at 05:00 up to 11:00 a.m. and from 16:00 to 22:30 p.m. The number of sites surveyed for median and large size mammals was five on cerrado stricto sensu, 11 on cerradão, 10 on gallery forest, and seven on deciduous forest. Disturbed, anthropic habitat surveys were not quantified but were the commonest environment in the region (e.g. pastures and peri-urban sites). The habitats of gallery forest, cerradão, and deciduous forest were the best sampled environments (at similar rates), and the habitats of cerrado sensu stricto (with no bat sampling) and human disturbed environments (with neither bat nor small terrestrial mammal sampling) were the less ones. Interviews with native residents were used to obtain additional records. Mammalian species systematic adopted was that of WILSON \& REEDER (2005).

Revista Brasileira de Zoologia 24 (2): 426-435, junho 2007 
The frequency of records for each species (not trappable in traps and mist nets) was calculated for each sampled environment, functioning as an ecological unit.

For trapping terrestrial small mammals, 30 to 32 national wire live traps $(40 \times 20 \times 20 \mathrm{~cm})$ were used daily on the ground level, baited with bacon, totaling 430 trap-nights. During the last fieldwork, however, we used 20 large traps and 10 smaller ones $(20 \times 10 \times 10 \mathrm{~cm})$ in a deciduous forest transect line near Santa Terezinha farm (90 trap-nights). Traps were separated in two or three sampling areas at Princesinha (180 trap-nights) and Califórnia (160 trap-nights) farms, and placed at different environments in the region studied (cerrado sensu stricto: 60 trap-nights; cerradão: 90 trap-nights; semideciduous gallery forest: 60 trap-nights; deciduous forest: 220 trap-nights) following a transect line (20 m of distance between each trap). Body mass and measurements of small mammals were taken for head and body (snout to rump) length, tail length, hind-foot length without claws, and ear length, to the nearest millimeter.

For bat sampling, three mist-nets $(9 \mathrm{~m} \mathrm{x} 2.5 \mathrm{~m})$ were set during $2 \mathrm{~h}$ and $30 \mathrm{~min}$ to $3 \mathrm{~h}$ and 30 min periods after the twilight (usually at $19 \mathrm{~h}$, local time) mainly on streams and trails but also in small forest gaps during April and May 2002. Mist-nets were set for two consecutive nights in each environment during the first fieldwork at the Princezinha farm (four nights; $663.8 \mathrm{~m}^{2} . \mathrm{h}$ ), and two nights in the 2nd one (Califórnia farm: $225 \mathrm{~m}^{2} . h$ ), due to the intense winter cold. The total sampling effort was $18.5 \mathrm{~h}$ with 45 to $67.5 \mathrm{~m}^{2}$ of mist-nets set per hour, totaling $888.8 \mathrm{~m}^{2} . \mathrm{h}$. The effort per habitat was as follows: cerradão, $247.5 \mathrm{~m}^{2}$.h; gallery forest, $303.8 \mathrm{~m}^{2} . \mathrm{h}$, and decidual forest, $337.5 \mathrm{~m}^{2}$. Mist-net sampling effort follows the methodology proposed by STraube \& Bianconi (2002).

Voucher specimens are deposited at the Museu de Zoologia da Universidade de São Paulo (MZUSP), São Paulo (São Paulo state), Universidade Federal de Santa Maria (UFSM), Santa Maria (Rio Grande do Sul state), and Museu de História Natural “Capão da Imbuia" (MHNCI), Curitiba (Paraná state), Brazil.

\section{RESULTS}

The region of Bodoquena Mountains revealed 56 mammal species. The more representative groups registered were the Order Carnivora (15 species), Rodentia (12), Chiroptera (10), Didelphimorphia (5), Artiodactyla (4), and Cingulata (3) (Tab. I, Fig.1). Tracks ( $\mathrm{N}=19$ species), direct observation in the field $(\mathrm{N}=11)$, mist-nets $(\mathrm{N}=10)$, and traps $(\mathrm{N}=9)$ were the main methods that contributed with a higher number of species surveyed.

Of the 56 species registered, eight (14.3\%) are threatened in Brazil according to Iвама (2003). Emphasis should be given to the carnivores, with six species listed under some risk categories in the region. According to the IUCN (2006), however, threatened species sum nine (16.1\%), with Carnivora being the most threatened group, with four species under the Near Threatened category and one under Endangered category. Non-carnivore large sized species under some risk categories were the
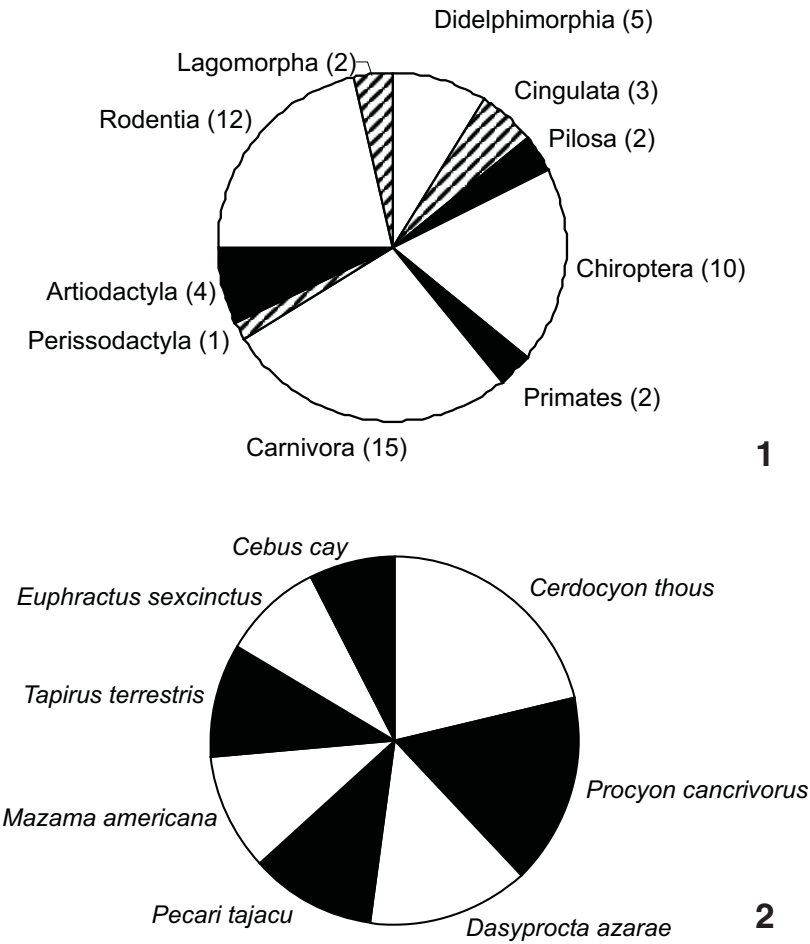

Figures 1-2. (1) Comparative view of mammal species richness at Bodoquena Mountains, Mato Grosso do Sul state, southwestern Brazil. Number of species is in parenthesis; (2) abundance of the most common mammal species at the same region (except those trapped with mist nets and live traps).

Giant anteater Myrmecophaga tridactyla and the Tapir Tapirus terrestris (Tab. I).

Medium-sized mammal species were commonly sampled in the neighborhoods of the SBNP. Species more frequently recorded were: Crab-eating fox Cerdocyon thous (17 records), Crab-eating raccon Procyon cancrivorus (13), Agouti Dasyprocta azarae (11), Collared peccary Pecari tajacu (9), Red brocket deer Mazama americana (8), T. terrestris (8), Yellow armadillo Euphractus sexcinctus (7), and Brown capuchin monkey Cebus cay (6) (Fig.2). Several carnivore species were uncommon or rare (all with one or two records), such as the Coati Nasua Nasua, the Tayra Eira barbara, the Lesser Grison Galictis cuja, the Maned wolf Chrysocyon brachyurus, and small felid species, as well as the Black howler monkey Alouatta caraya and the White-lipped peccary Tayassu pecari (Tab. I).

The overall non-volant small mammal trapping success was $9.1 \%$, considering all habitats sampled. Among terrestrial small mammals, the Gray short-tailed mouse opossum Monodelphis domestica (3.0\%) and the Spiny rat Thrichomys pachyurus $(1.9 \%)$ were the commonest species trapped in deciduous forests $(4.5 \%$ and $3.2 \%$, respectively, in this environment), while the Rice rat Cerradomys scotti (1.6\%) was mostly 
Table I. Estimated abundances of mammals in Bodoquena Mountains, Mato Grosso do Sul state, southwestern Brazil.

\begin{tabular}{|c|c|c|c|c|c|c|c|c|}
\hline Scientific name & Common name & $\mathrm{Ce}$ & $\mathrm{Cd}$ & Fs & $\mathrm{Fd}$ & $\mathrm{Hm}$ & Total & $\begin{array}{c}\text { Record } \\
\text { type }\end{array}$ \\
\hline \multicolumn{9}{|l|}{ Didelphimorphia } \\
\hline Caluromys lanatus (Olfers, 1818) & Woolly Opossum & & & & & 1 & 1 & B \\
\hline Didelphis albiventris Lund, 1840 & White-eared Opossum & & & & & 1 & 1 & $\mathrm{D}$ \\
\hline Micoureus constantiae (Thomas, 1904) & Woolly Mouse Opossum & & 3 & & & & 3 & $\mathrm{~L}$ \\
\hline Monodelphis domestica (Wagner, 1842) & Gray Short-tailed Opossum & 2 & 1 & 0 & 10 & & 13 & L \\
\hline Thylamys macrurus (Olfers, 1818) & Thick-Tailed Mouse Opossum & & & & 3 & & 3 & L \\
\hline \multicolumn{9}{|l|}{ Cingulata } \\
\hline Dasypus novemcinctus (Linnaeus, 1758) & Nine-banded Armadillo & 1 & 2 & 1 & 1 & & 5 & $\mathrm{~T}$ \\
\hline Euphractus sexcinctus (Linnaeus, 1758) & Yellow Armadillo & 1 & 2 & & & 4 & 7 & $\mathrm{~T}, \mathrm{R}$ \\
\hline Tolypeutes matacus (Desmarest, 1804) NT & Three-banded Armadillo & & & & & & 1 & I \\
\hline \multicolumn{9}{|l|}{ Pilosa } \\
\hline Myrmecophaga tridactyla (Linnaeus, 1758) * NT & Giant Anteater & & 1 & & 1 & & 2 & $\mathrm{~T}, \mathrm{R}$ \\
\hline Tamandua tetradactyla (Linnaeus, 1758) & Collared Anteater & 2 & 1 & & & & 3 & $\mathrm{D}, \mathrm{R}$ \\
\hline \multicolumn{9}{|l|}{ Chiroptera } \\
\hline Anoura caudifer (E. Geoffroy, 1818) & Tailed Failess Bat & & & 1 & & & 1 & M \\
\hline Artibeus jamaicensis (Leach, 1821) & Jamaican Fruit-eating Bat & & 9 & 6 & 9 & & 24 & M \\
\hline Artibeus lituratus (Olfers, 1818) & Large Fruit-eating Bat & & & 1 & & & 1 & M \\
\hline Carollia perspicillata (Linnaeus, 1758) & Seba's Short-tailed Bat & & 2 & 4 & 2 & & 8 & M \\
\hline Desmodus rotundus (E. Geoffroy, 1810) & Vampire Bat & & & & 5 & & 5 & M \\
\hline Glossophaga soricina (Pallas, 1766) & Pallas's Long-tongued Bat & & & & 3 & & 3 & M \\
\hline Platyrrhinus lineatus (E. Geoffroy, 1810) & White-lined Bat & & & 6 & & & 6 & M \\
\hline Sturnira lilium (E. Geoffroy, 1810) & Little Yellow-shouldered Bat & & 1 & 5 & 2 & & 8 & M \\
\hline Eptesicus brasiliensis (Desmarest, 1819) & Brazilian Brown Bat & & & 2 & & & 2 & M \\
\hline Myotis sp. (Findley, 1972) & bat & & & 1 & & & 1 & M \\
\hline \multicolumn{9}{|l|}{ Primates } \\
\hline Alouatta caraya (Humboldt, 1812) & Black Howler Monkey & 1 & & & & & 1 & $S$ \\
\hline Cebus cay (Illiger, 1815) & Brown Capuchin Monkey & & 1 & 4 & 1 & & 6 & $S$ \\
\hline \multicolumn{9}{|l|}{ Carnivora } \\
\hline Cerdocyon thous (Linnaeus, 1766) & Crab-eating Fox & 2 & 7 & 2 & 3 & 3 & 17 & $\mathrm{~T}, \mathrm{R}$ \\
\hline Chrysocyon brachyurus (Illiger, 1815) * NT & Maned Wolf & & 1 & & 1 & & 2 & $\mathrm{~T}, \mathrm{~F}$ \\
\hline Lycalopex vetulus (Lund, 1842) & fox & 1 & 2 & 1 & & 1 & 5 & $\mathrm{~T}$ \\
\hline Puma concolor (Linnaeus, 1771) * NT & Puma & 1 & 2 & 1 & 1 & & 5 & $\mathrm{~T}, \mathrm{~B}$ \\
\hline Puma yagouaroundi (É. Geoffroy Saint Hilaire, 1803) & Jaguarundi & & & 1 & & & 1 & D \\
\hline Leopardus pardalis (Linnaeus, 1758) * & Ocelot & 1 & & 1 & & & 2 & $\mathrm{~T}, \mathrm{~B}$ \\
\hline Oncifelis colocolo (Molina, 1782) * NT & Pampas Cat & & & & & 1 & 1 & $\mathrm{R}$ \\
\hline Panthera onca (Linnaeus, 1758) * NT & Jaguar & & & & & & & I \\
\hline Nasua nasua (Linnaeus, 1766) & South American Coati & & 1 & & & & 1 & $R, B$ \\
\hline Procyon cancrivorus (G. Cuvier, 1798) & Crab-eating Raccoon & & 4 & 7 & 1 & 1 & 13 & $\mathrm{~T}$ \\
\hline Conepatus chinga (Molina, 1782) & Molina's Hog-nosed Skunk & & & & & & & 1 \\
\hline Eira Barbara (Linnaeus, 1758) & Tayra & & 1 & & & & 1 & $\mathrm{R}$ \\
\hline Galictis cuja (Molina, 1782) & Lesser Grison & & & 1 & & & 1 & $\mathrm{D}$ \\
\hline Lontra longicaudis (Olfers, 1818) & Long-tailed Otter & & & 2 & & & 2 & $\mathrm{~T}$ \\
\hline Pteronura brasiliensis (Gmelin, 1788) * EN & Giant Otter & & & 1 & & & 1 & 1 \\
\hline
\end{tabular}


Table I. Continued.

\begin{tabular}{|c|c|c|c|c|c|c|c|c|}
\hline Scientific name & Common name & $\mathrm{Ce}$ & $\mathrm{Cd}$ & Fs & $\mathrm{Fd}$ & $\mathrm{Hm}$ & Total & $\begin{array}{c}\text { Record } \\
\text { type }\end{array}$ \\
\hline \multicolumn{9}{|l|}{ Perissodactyla } \\
\hline Tapirus terrestris (Linnaeus, 1758) * VU & Tapir & 1 & 3 & 4 & & & 8 & $\mathrm{~T}$ \\
\hline \multicolumn{9}{|l|}{ Artiodactyla } \\
\hline Mazama americana (Erxleben, 1777) & Red Brocket Deer & & 7 & 1 & & & 8 & $\mathrm{~T}$ \\
\hline Mazama gouazoubira (G. Fisher, 1814) & Gray Brocket Deer & & 1 & 1 & 2 & 1 & 5 & $\mathrm{~T}, \mathrm{D}$ \\
\hline Pecari tajacu (Linnaeus, 1758) & Collared Peccary & 1 & 4 & 1 & 1 & 2 & 9 & $\mathrm{~T}, \mathrm{D}$ \\
\hline Tayassu pecari (Link, 1795) & White-lipped Peccary & & 1 & 1 & & & 2 & $\mathrm{~T}, \mathrm{~S}$ \\
\hline \multicolumn{9}{|l|}{ Rodentia } \\
\hline Cavia aperea Erxleben, 1777 & Brazilian Guinea Pig & & 1 & & 1 & & 2 & $\mathrm{~T}$ \\
\hline Dasyprocta azarae (Lichtenstein, 1823) VU & Azara's Agouti & 1 & 3 & 4 & 2 & 1 & 11 & $\mathrm{~T}$ \\
\hline Agouti paca (Linnaeus, 1758) & Spotted Paca & & & 3 & 1 & & 4 & $\mathrm{~T}, \mathrm{~S}$ \\
\hline Hydrochaerus hydrochaeris (Linnaeus, 1758) & Capybara & & & 4 & & & 4 & $\mathrm{~T}$ \\
\hline Thrichomys pachyurus (Wagner, 1845) & Spiny Rat & & 1 & & 7 & & 8 & L \\
\hline Akodon montensis Thomas, 1913 & Grass Mouse & & 1 & & & & 1 & L \\
\hline Calomys sp. Waterhouse, 1837 & Vesper Mouse & & & 1 & & & 1 & L \\
\hline Cerradomys scotti (Langguth \& Bonvicino, 2002) & Rice Rat & 1 & 5 & & 1 & & 7 & L \\
\hline Hylaeamys megacephalus (Fischer, 1814) & Rice Rat & & & 1 & & & 1 & L \\
\hline Nectomys rattus (Pelzen, 1883) & Water Rat & & & 2 & & & 2 & $\mathrm{~L}$ \\
\hline Oligoryzomys nigripes (Olfers, 1818) & Black-footed Pygmy Rice Rat & & & & 1 & & 1 & $\mathrm{D}$ \\
\hline Rattus rattus (Linnaeus, 1758) & House Rat & & & & & 1 & 1 & $\mathrm{D}$ \\
\hline \multicolumn{9}{|l|}{ Lagomorpha } \\
\hline Lepus capensis (Linnaeus, 1758) & Cape Hare & 2 & & & & 1 & 3 & $D, F$ \\
\hline Sylvilagus brasiliensis (Linnaeus, 1758) & Tapiti & & 2 & & 2 & & 4 & $\mathrm{~T}, \mathrm{D}$ \\
\hline
\end{tabular}

(Ce) cerrado sensu stricto, $(\mathrm{Cd})$ cerradão, (Fs) semideciduous forest, (Fd) deciduous forest, (Hm) human disturbed environment, (D) direct observation, $(S)$ sound, $(T)$ track, $(M)$ mist-net, (R) run over on roads, (L) live trap, (F) feces, (B) fur and bones, (I) interview. Threatened species following IBAMA (2003)* and IUCN (2006): (VU) vulnerable, (NT) near threatened, (EN) endangered. Frequencies are given as one record per site when a given species was present, except for bats and small trappable mammals for which results are given as the total number of individuals captured.

sampled in the cerradão (5.6\%). Marsupials such as the Palebellied woolly mouse opossum Micoureus constantiae and the Thick-tailed mouse opossum Thylamys macrurus were less trapped $(0.7 \%$ for both species), in disturbed cerradão $(3.3 \%)$ and deciduous forest (1.4\%), respectively (Tab. I). Body mass and body size lengths of terrestrial small mammals sampled are shown in table II. The majority of these species (82\%) had weight less than $100 \mathrm{~g}$ on average.

Ten bat species were recorded during fieldwork. The more frequent species were Jamaican Fruit-eating bat Artibeus jamaicensis (24 individuals), Seba's short-tailed bat Carollia perspicillata and Little yellow-shouldered bat Sturnira lilium (both with eight individuals), and the rarer species were Tailed failess bat Anoura caudifer, Large fruit-eating bat Artibeus lituratus, Brazilian brown bat Eptesicus brasiliensis and Myotis sp., all with one to two records. White-lined bat Platyrrhinus lineatus was captured only in semideciduous gallery forests ( $\mathrm{n}=6$ individuals), while Vampire bat Desmodus rotundus $(\mathrm{n}=5)$ and Pallas's long-tongued bat Glossophaga soricina $(\mathrm{n}=3)$ were obtained only in deciduous forest (Tab. I).

Habitats richer in species (including the small mammals) were the semideciduous gallery forest (30 species), cerradão (28) and deciduous forest (24). By contrast, the cerrado sensu stricto and human disturbed environments were the less diverse habitats (15 and 13, respectively). Artibeus jamaicensis, C. thous, and $P$. cancrivorus were the commonest species at gallery forest and cerradão, that is, the best sampled environments. However, $E$. sexcinctus and $C$. thous were the most common in the human disturbed environments (Tab. I).

\section{DISCUSSION}

Despite the extensive areas of pasture, agriculture and those used by mineral extraction activities, the diagnostic status of mammals of SBNP neighborhoods revealed a reasonable richness and a structured community. It is important to notice that species number recorded here will tend to increase at least 
Table II. Mass ( $\mathrm{g}$ ) and body size length ( $\mathrm{mm}$ ) of small mammals from the Bodoquena Mountains, Mato Grosso do Sul state, southwestern Brazil. Means \pm standard deviations are provided for each sex and species. Observed range is in parentheses. Foot is without claws.

\begin{tabular}{|c|c|c|c|c|c|c|c|}
\hline Species & Sex & $\mathrm{N}$ & Mass & Body & Tail & Foot & Ear \\
\hline \multicolumn{8}{|l|}{ Didelphimorphia } \\
\hline Micoureus constantiae & Fêmea & 3 & $\begin{array}{c}66 \pm 36 \\
(35-106)\end{array}$ & $\begin{array}{c}135.3 \pm 27.4 \\
(113-166)\end{array}$ & $\begin{array}{c}195.3 \pm 26.9 \\
(166-219)\end{array}$ & $\begin{array}{c}21.9 \pm 1.1 \\
(21-23)\end{array}$ & $\begin{array}{c}21.3 \pm 1.2 \\
(20.3-22.7)\end{array}$ \\
\hline \multirow[t]{3}{*}{ Monodelphis domestica } & Macho & 2 & $55 \pm 1$ & $129.4 \pm 9.3$ & $73.7 \pm 2.5$ & $15.4 \pm 4.7$ & $20.1 \pm 0.1$ \\
\hline & Fêmea & 1 & 60 & 132.6 & 81.5 & 18.7 & 16.8 \\
\hline & & 3 & $\begin{array}{c}56 \pm 3 \\
(54-60)\end{array}$ & $\begin{array}{c}130.5 \pm 6.8 \\
(122.8-136.0)\end{array}$ & $\begin{array}{c}76.3 \pm 4.8 \\
(72.0-81.5)\end{array}$ & $\begin{array}{c}16.5 \pm 3.8 \\
(12.1-18.7)\end{array}$ & $\begin{array}{l}19.0 \pm 1.9 \\
(16.8-20.2)\end{array}$ \\
\hline Thylamys macrurus & Macho & 3 & $\begin{array}{c}39 \pm 4 \\
(35-41)\end{array}$ & $\begin{array}{c}110.8 \pm 9.0 \\
(101.1-118.8)\end{array}$ & $\begin{array}{c}144.3 \pm 7.3 \\
(136.0-150.0)\end{array}$ & $\begin{array}{c}17.1 \pm 0.4 \\
(16.8-17.5)\end{array}$ & $\begin{array}{c}22.3 \pm 2.4 \\
(20.8-25.0)\end{array}$ \\
\hline \multicolumn{8}{|l|}{ Rodentia } \\
\hline Akodon montensis & Fêmea & 1 & 35 & 101.6 & 88.6 & 23.1 & 17.4 \\
\hline Calomys sp. & Fêmea & 1 & 22 & 89.7 & 71 & 18.4 & 13.8 \\
\hline Nectomys rattus & Macho & 1 & 153 & 185 & 201 & 47.2 & 22.1 \\
\hline Oligoryzomys nigripes & Macho & 1 & 25 & 94.2 & 141 & 25.1 & 16.5 \\
\hline \multirow[t]{3}{*}{ Hylaeamys megacephalus } & Macho & 1 & 59 & 129 & 123 & 29.7 & 20.2 \\
\hline & Fêmea & 1 & 60 & 130.6 & 130 & 27.9 & 21.6 \\
\hline & & 2 & $\begin{array}{c}60 \pm 1 \\
(59-60)\end{array}$ & $\begin{array}{c}129.8 \pm 1.1 \\
(129.0-130.6)\end{array}$ & $\begin{array}{c}126.5 \pm 4.9 \\
(123-130)\end{array}$ & $\begin{array}{c}28.8 \pm 1.3 \\
(27.9-29.7)\end{array}$ & $\begin{array}{c}20.9 \pm 1 \\
(20.2-21.6)\end{array}$ \\
\hline \multirow[t]{3}{*}{ Cerradomys scotti } & Macho & 3 & $49 \pm 24$ & $113.0 \pm 26.8$ & $141.4 \pm 19.8$ & $28.4 \pm 3.0$ & $16.4 \pm 1.3$ \\
\hline & Fêmea & 2 & $60 \pm 23$ & $116.9 \pm 20.0$ & $151.0 \pm 35.3$ & $30.0 \pm 1.3$ & $19.2 \pm 0.9$ \\
\hline & & 5 & $\begin{array}{l}53 \pm 21 \\
(26-76)\end{array}$ & $\begin{array}{l}114.6 \pm 21.5 \\
(89.1-142.0)\end{array}$ & $\begin{array}{l}145.3 \pm 23.2 \\
(120.5-176)\end{array}$ & $\begin{array}{c}29.2 \pm 2.1 \\
(26.3-31.5)\end{array}$ & $\begin{array}{c}17.8 \pm 1.9 \\
(15.5-19.9)\end{array}$ \\
\hline Rattus rattus & Macho & 1 & 163 & 166 & 200.3 & 34.7 & 24.4 \\
\hline Thrichomys pachyurus & Fêmea & 2 & $\begin{array}{c}266 \pm 42 \\
(236-296)\end{array}$ & $\begin{array}{c}222.6 \pm 31.6 \\
(200.3-245.0)\end{array}$ & $\begin{array}{l}184 \pm 1.4 \\
(183-185)\end{array}$ & $\begin{array}{c}42.5 \pm 0.6 \\
(42.1-43.0)\end{array}$ & $\begin{array}{c}23 \pm 1.4 \\
(22-24)\end{array}$ \\
\hline
\end{tabular}

slightly since the inventory program is in progress, particularly in the interior of the SBNP, which is well preserved.

Thylamys macrurus has been recorded in the Paraguayan subtropical forest (PALMA 1995) and in the Cerrado, being also attributed to inhabit the eastern Brazilian Atlantic forest (EISENBERG \& REDFoRD 1999). In fact, our present analysis does not support the suggested occurrence of T. macrurus in the eastern dense and mixed forest of Brazil (see PaLma \& VieIRA 2006), being this species an inhabitant of the deciduous forest (this study) and the adjacent Cerrado biome in southwestern Brazil (CARMignotTo \& MONForT 2006).

Another poorly known marsupial is the mouse opossum M. constantiae (EMmons \& FeER 1997), which has its distribution extended southward in Brazil on the basis of VieIRA's record (1955: Campo Grande) and this report, with possible occurrence to adjacent central Paraguay. This species is also known from Bolivia and northwestern Argentina (ANDERson 1997, EISENBERg \& REDFORD 1999).

The occurrence of the Pampas cat Oncifelis colocolo is a new record for the highlands of Mato Grosso do Sul state, confirming its range westward in Brazil in biomes adjacent to Pantanal (Vieira 1955, Silveira 1995, FonseCa et al. 1996, BordignoN et al. 2006). The distribution of this species is thought to be continuous from Mato Grosso (western Brazil) to central Argentina, throughout open areas including savannas and dry forests.

Clyomys laticeps was already reported for the Bodoquena region (Ávila PIRES \& WUTKE 1981), being a typical species of the Cerrado and Pantanal biomes (Fonseca et al. 1996).

Further species probably occur in the SBNP and region, those specially surveyed by interviews, such as the Jaguar Panthera onca and Three-banded armadillo Tolypeutes matacus, which are threatened in Brazil (IBAma 2003, IUCN 2006). Some additional rodent species are expected for the region, since a non-identified terrestrial small mammal (near $200 \mathrm{~g}$ ), very different from the remaining documented taxa (mainly by its tail morphology, that was brush-like in its tip), was seen in a rocky outcrop in deciduous forest. Grassland and scrubland species such as the Slender mouse opossum Gracilinanus agilis (Burmeister, 1854), 
the Mouse opossum Cryptonanus sp., the Grass mouse Necromys lasiurus (Lund, 1841) and the Vesper mouse Calomys tener (Winge, 1887) are also expected for the region, since they occur in the adjacent Cerrado (Rodrigues et al. 2002). Furthermore, future surveys in Bodoquena Mountains can reveal new small mammalian species for Brazil, mainly with Chacoan relationships, which is based on the similar environmental characteristics (see IbGE 1992) and on the semi-arid holocenic past of the region (Palma 1995).

The presence of several other mammal species, such as the Bare-tailed woolly opossum Caluromys philander (Linnaeus, 1758), Lutrine opossum Lutreolina crassicaudata (Desmarest, 1804), Murine mouse opossum Marmosa murina (Linnaeus, 1758), Gray four-eyed opossum Philander opossum (Linnaeus, 1758) (Didephimorphia), Southern naked-tailed armadillo Cabassous unicinctus (Linnaeus, 1758) (Cingulata), Margay Leopardus wiedii (Schinz, 1821), Oncilla Leopardus tigrinus (Schreber, 1775) (Carnivora), Arboreal rice rat Oecomys bicolor (Tomes, 1860), Pygmy rice rat Oligoryzomys fornesi (Massoia, 1973), Brazilian porcupine Coendou prehensilis (Linnaeus, 1758), and Spiny rat Proechimys longicaudatus (Rengger, 1830) (Rodentia), could be inferred for the region of Bodoquena, based on studies carried out in the transitional areas of Cerrado/Atlantic Forest of adjacent states (JoHnson et al. 1999, RodRigues et al. 2002, Costa 2003), the Chaco of adjacent countries (REDFord \& EIsenberg 1992, Anderson 1997, Eisenberg \& RedFord 1999), and the Brazilian Pantanal of Corumbá (e.g. Schaller 1983, AlHo et al. 1987, Mauro \& Campos 2000). However, local residents of Bodoquena Mountains pointed out that some species such as the Pampas Deer Ozotoceros bezoarticus (Linnaeus, 1758) do not occur in the region but only far away in the Pantanal. This species may have been locally extinct in the region, since it is expected to dwell in most range of the Cerrado biome (FonsecA et al. 1996, Eisenberg \& Redford 1999).

Gallery forest and cerradão were richer in mammal species, as seen elsewhere (Bonvicino et al. 1996, Johnson et al. 1999). This was correlated to the higher availability of these habitats in the neighborhoods of Bodoquena Mountains, and also to the more vertical complexity of these forests. Nonetheless, part of these results could be explained by the higher sampling effort in these habitats. The cerrado sensu stricto was rare in the region, and this can justify the low mammal richness seen for this habitat. Deciduous forests, although being mostly concentrated inside of the SBNP (and not in its neighborhoods), also revealed a richer fauna, which is very similar to that found in adjacent habitats of Cerrado.

Human disturbed environments (mainly roads and rural to urban areas) were quite frequent in the surroundings of Bodoquena Mountains but revealed lower species richness. This should be interpreted in light of this last habitat was not sampled for bats and small terrestrial mammals, but mainly for medium and large size ones. Therefore, dominances of opportunistic species such as C. thous and E. sexcinctus (see MотTA-
JR et al. 1994, BEZERRA et al. 2001) have occurred in these disturbed habitats. A fact that deserves emphasis is the widespread presence of ungulates (even T. terrestris), Crab-eating fox $C$. thous, Crab-eating raccoon $P$. cancrivorus, Agouti D. azarae and Brown capuchin monkey C. cay in several localities of the neighborhoods. As these species usually are potential prey for the large carnivorous mammals (FARREL et al. 2000), and are also seed dispersers agents (e.g. Hallwachs 1986, Bodmer 1991, MotTAJúNIOR et al. 1994, GATTI et al. 2006), they are important for the future management of the SBNP.

Felids probably are more diverse in the region since the species surveyed (e.g. P. concolor, L. pardalis and O. colocolo) point out for a higher richness than the five species recorded, since communities where large predators, such as $P$. concolor, occur are rich species communities, with several carnivorous, omnivorous and herbivorous mammalian species (SCHALLER 1983, Chiarello 1999, Quadros \& Cáceres 2001). A species highly threatened in the mountains would be the Jaguar $P$. onca (if confirmed its current presence in the region), due to its wide spatial requirements (SCHaLler \& Crawshaw 1980). Only the SBNP area (nearly $10 \mathrm{~km}$ in width) is probably unsuitable for its conservation. Thus it is necessary to establish connection between the SBNP and the adjacent protected lands connected with the Pantanal (where $P$. onca has rather stable populations; ZiMMERMANN et al. 2005), such as the indigenous reserve at northwest, throughout corridor implantations.

Our results revealed threatened species, distribution extensions, and new regional species records for Bodoquena Mountains, which are a transitional Atlantic Forest - Cerrado region. Probably, the regional species diversity will increase with wet season surveys, which can reveal undocumented species. Moreover, more survey efforts particularly for small mammal species (bats, rodents and marsupials) will increase the species diversity for the region. Additionally, Bodoquena Mountains show great potential for endemic species, since is a rocky, deciduous massif, isolated of other mountains in central South America. The fact that the mountains are mainly composed by undisturbed forests, apart from the surrounding plateau and flood plains (which are covered mainly by Cerrado, sometimes highly disturbed by pasture and agricultural activities), is important for regional species diversity.

The importance of the SBNP neighborhoods is increased when we point out the presence of threatened species. These data must be considered for faunal conservation practices in the SBNP as a whole. Nonetheless, wild mammals are also responsible for damages in human economic activities along the neighborhoods of the SBNP (pers. obs.), as has been reported elsewhere (Zimmermann et al. 2005). Interviews with residents revealed the Puma $P$. concolor (responding by predation on cattle) and the peccaries $T$. pecari and $P$. tajacu (by feeding on plantations) as the main responsible for them.

The observation of mammals killed on roads in Bodoquena Mountains' neighborhoods (including threatened species such 
as the Pampas cat O. colocolo and Giant anteater M. tridactyla) highlights the threat that this factor represents to wild mammal populations (e.g. VieIra 1996). Since the region of Bodoquena as a whole will tend to develop rapidly due to tourism (DAMASCENOJúNIOR et al. 2000), the traffic of vehicles will probably increase, leading to higher mortality rates on roads.

\section{ACKNOWLEDGMENTS}

To G. Bianconi for helping in bat, J. Quadros for mediansized mammal, and A.P. Carmignotto for rodent and marsupial identifications. GEMAP and PROPP at Universidade Estadual do Mato Grosso do Sul (in the person of Afrânio S. Soriano and Vito Comar), the Fundação Neotropica do Brasil and the Ministério do Meio Ambiente (ProBio/Brazilian Government) gave support for this study. We are in debt with anonymous referees for helping in the final version of the manuscript.

\section{REFERENCES}

Aв'SAber, A.N. 1988. O pantanal matogrossense e a teoria dos refúgios. Revista Brasileira de Geografia 50: 9-57.

Alho, C.R.J.; T.E. Lacher; Z.M.S. Campos Jr \& H.C. Gonçalves. 1987. Mamíferos da Fazenda Nhumirim, sub-região de Nhecolândia, Pantanal do Mato Grosso do Sul. I - Levantamento preliminar das espécies. Revista Brasileira de Zoologia 4: 151-164.

Anderson, S. 1997. Mammals of Bolivia: taxonomy and distribution. Bulletin of the American Museum of Natural History 231: 1-652.

Ávila Pires, F.D. \& M.R.C. Wutke. 1981. Taxonomia e evolução de Clyomys Thomas, 1916 (Rodentia, Echimyidae). Revista Brasileira de Zoologia 41: 529-534.

BeCKer, M. \& J.C. DAlponte. 1999. Rastros de mamíferos brasileiros: um guia de campo. Brasília, Universidade de Brasília, VIII+180p.

Bezerra, A.M.R.; F.H.G. Rodrigues \& A.P. Carmignotto. 2001. Predation of rodents by the yellow armadillo (Euphractus sexcinctus) in Cerrado of the central Brazil. Mammalia 65: 86-88.

BODMER, R.E. 1991. Strategies of seed dispersal and seed predation in Amazonian ungulates. Biotropica 23: 255-261.

Bonvicino, C.R.; R. Cerqueira \& V.A. Soares. 1996. Habitat use by small mammals of upper Araguaia River. Revista Brasileira de Biologia 56: 761-767.

Bordignon, M.O.; N.C. CÁceres; A.O. França; J. Casella \& C.F. VARGAS. 2006. Inventário da mastofauna no Complexo Aporé - Sucuriú, p. 129-142. In: T.C.S. PAgotTo \& P.R. Souza (Eds). Biodiversidade do Complexo Aporé-Sucuriú: subsídios à conservação e manejo do bioma Cerrado. Campo Grande, Editora da UFMS, 304p.

Carmignotto, A.P. \& T. Monfort. 2006. Taxonomy and distribution of the Brazilian species of Thylamys (Didelphimorphia, Didelphidae). Mammalia 70 (1-2): 126-144.

Chiarello, A.G. 1999. Effects of fragmentation of the Atlantic forest on mammal communities in south-eastern Brazil. Biological Conservation 89: 71-82.

CosTA, L.P. 2003. The historical bridge of between the Amazon adn the Atlantic Forest of Brazil: a study of molecular phylogeography with small mammals. Journal of Biogeography 30: 71-86.

Damasceno-Júnior, G.A.; J.N. Nakajima \& U.M. Resende. 2000. A floristic survey of the Rio Negro, Rio Aquidauana and Rio Miranda watersheds (headwaters) of the Pantanal, Mato Grosso do Sul, Brazil, p. 34-48. In: P.W. Willink; B. ChernofF; L.E. Alonso; J.R. Montambault \& R. Lourival (Eds). A biological assessment of the aquatic ecosystems of the Pantanal, Mato Grosso do Sul, Brazil. Washington, Conservation International, Rapid Assessment Program 18, 306p.

EISENBERG, J.F. \& K.H. REDFORD. 1999. Mammals of the neotropics - the central neotropics: Ecuador, Peru, Bolivia, Brazil. Chicago, University of Chicago Press, X+609p.

EMmONs, L.H. \& F. FEER. 1997. Neotropical rainforest mammals: a field guide. Chicago, University of Chicago Press, XVI+307p.

FARRel, L.E; J. Roman \& M.E. Sunquist. 2000. Dietary separation of sympatric carnivores identified by molecular analysis of scats. Molecular Ecology 9: 1583-1590.

Fonseca, G.A.B.; G. Herrmann; Y.R.L. Leite; R.A. Mittermeier; A.B. Rylands \& J.L. Patton. 1996. Lista anotada dos mamíferos do Brasil. Occasional Papers in Conservation Biology 4: 1-38.

Gatti, A.; R. Bianchi; C.R.X. Rosa \& S.L. Mendes. 2006. Diet of two sympatric carnivores, Cerdocyon thous and Procyon cancrivorus, in a restinga area of Espírito Santo state, Brazil. Journal of Tropical Ecology 22: 227-230.

HallwaChs, W. 1986. Agouts (Dasyprocta puntacta): the inheritors of guapinol (Hymenaea courbaril: Leguminosae), p. 285-304. In: A. Estrada \& T.H. Fleming (Eds). Frugivores and seed dispersal. Dordrecht, W. Junk Publishers, 392p.

Iвама. 2003. Instituto Brasileiro do Meio Ambiente e dos Recursos Naturais Renováveis. Lista das espécies da fauna brasileira ameaçadas de extinção. Instrução Normativa no. 3 do Ministério do Meio Ambiente, de 27 de maio de 2003. Available in the World Wide Web at: http://www.biodiversitas.org.br [Accessed on 11.X.2006]

IbGe. 1992. Manual técnico da vegetação brasileira. Rio de Janeiro, Manuais Técnicos em Geociências, 92p.

IUCN. 2006. 2006 IUCN red list of threatned species - database search. IUCN - World Conservation Union, Gand, Switzerland. Available in the World Wide Web at: http:// www.iucnredlist.org [Accessed on 11X.2006]

Johnson, M.A.; P.M. Saraiva \& D. Coelho. 1999. The role of gallery forests in the distribution of cerrado mammals. Revista Brasileira de Biologia 59: 421-427.

Mauro, R.A. \& Z. CAmpos. 2000. Fauna, p. 133-151. In: J.S.V. DA SILVA (Ed.). Zoneamento ambiental da borda oeste do Pantanal: maciço de Urucum e adjacências. Brasília, Embrapa, 211p. 
MotTa-Júnior, J.C.; J.A. Lombardi \& S.A. Talamoni. 1994. Notes on crab-eating fox (Dusicyon thous) seed dispersal and food habits in southeastern Brazil. Mammalia 58: 156-159.

Palma, A.R.T. \& E.M. Vieira. 2006. O gênero Thylamys no Brasil: história natural e distribuição geográfica. In: N.C. CÁCERES \& E.L.A. Monteiro-Filho (Eds). Os marsupiais do Brasil: biologia, ecologia e evolução. Campo Grande, UFMS, 364p.

Palma, R.E. 1995. Range expansion of two South American mouse opossum (Thylamys, Didelphidae) and their biogeographic implications. Revista Chilena de História Natural 68: 515-522.

Quadros, J. \& N.C. CÁCERES. 2001. Ecologia e conservação de mamíferos na Reserva Volta Velha, Estado de Santa Catarina, Brasil. Acta Biologica Leopoldensia 23: 213-224.

Redford, K.H. \& J.F. Eisenberg. 1992. Mammals of the neotropics - the southern cone: Argentina, Chile, Uruguay, Paraguay. Chicago, University of Chicago Press, 430p.

Rodrigues, F.H.G.; L. Silveira; A.T.A. Jácomo; A.P. Carmignotto; A.M.R. Bezerra; D.C. Coelho; H. Garbogini; J. Pagnozzi \& A. HAss. 2002. Composição e caracterização da fauna de mamíferos do Parque Nacional das Emas, Goiás, Brasil. Revista Brasileira de Zoologia 19: 589-600.

SCHALler, G.B. 1983. Mammals and their biomass on a Brazilian ranch. Arquivos de Zoologia 31: 1-36.

Schaller, G. \& P. Crawshaw, Jr. 1980. Movement patterns of the jaguar. Biotropica, Lawrence, 12: 161-168.

Silveira, L. 1995. Notes on the distribution and natural history of the pampas cat, Felis colocolo, in Brazil. Mammalia 59: 284-288.

Straube, F.C. \& G.V. Bianconi. 2002. Sobre a grandeza e a unidade utilizada para estimar esforço de captura com utilização de redes-de-neblina. Chiroptera Neotropical 8 (1-2): 150-152.

Streilen, K.E. 1982. Behavior, ecology, and distribution of South American marsupials, p. 231-250. In: M.A. MARES \& H. GeNOWAYS (Eds). Mammalian biology in South America. Pittsburg, University of Pittsburg, 539p.

VieIRA, C.O.C. 1955. Lista remissiva dos mamíferos do Brasil. Arquivos de Zoologia 8: 341-465.

Vieira, E.M. 1996. Highway mortality of mammals in central Brazil. Ciência e Cultura 48: 270-272.

Wilson, D.E. \& D.M. ReEder. 2005. Mammal species of the world: a taxonomic and geographic reference. Third Edition. Baltimore, The Johns Hopkins University Press, XXXV+2142p.

Zimmermann, A.; M.J. Walpole \& N. Leader-Williams. 2005. Cattle ranchers' attitudes to conflicts with jaguar Panthera onca in the Pantanal of Brazil. Oryx 39: 406-412.

Received in 19.V.2006; accepted in 15.V.2007.

Appendix I. Specimens collected by the authors in the study region. (UFSM) Universidade Federal de Santa Maria, (MHNCI) Museu de História Natural "Capão da Imbuia", (MZUSP) Museu de Zoologia, Universidade de São Paulo.

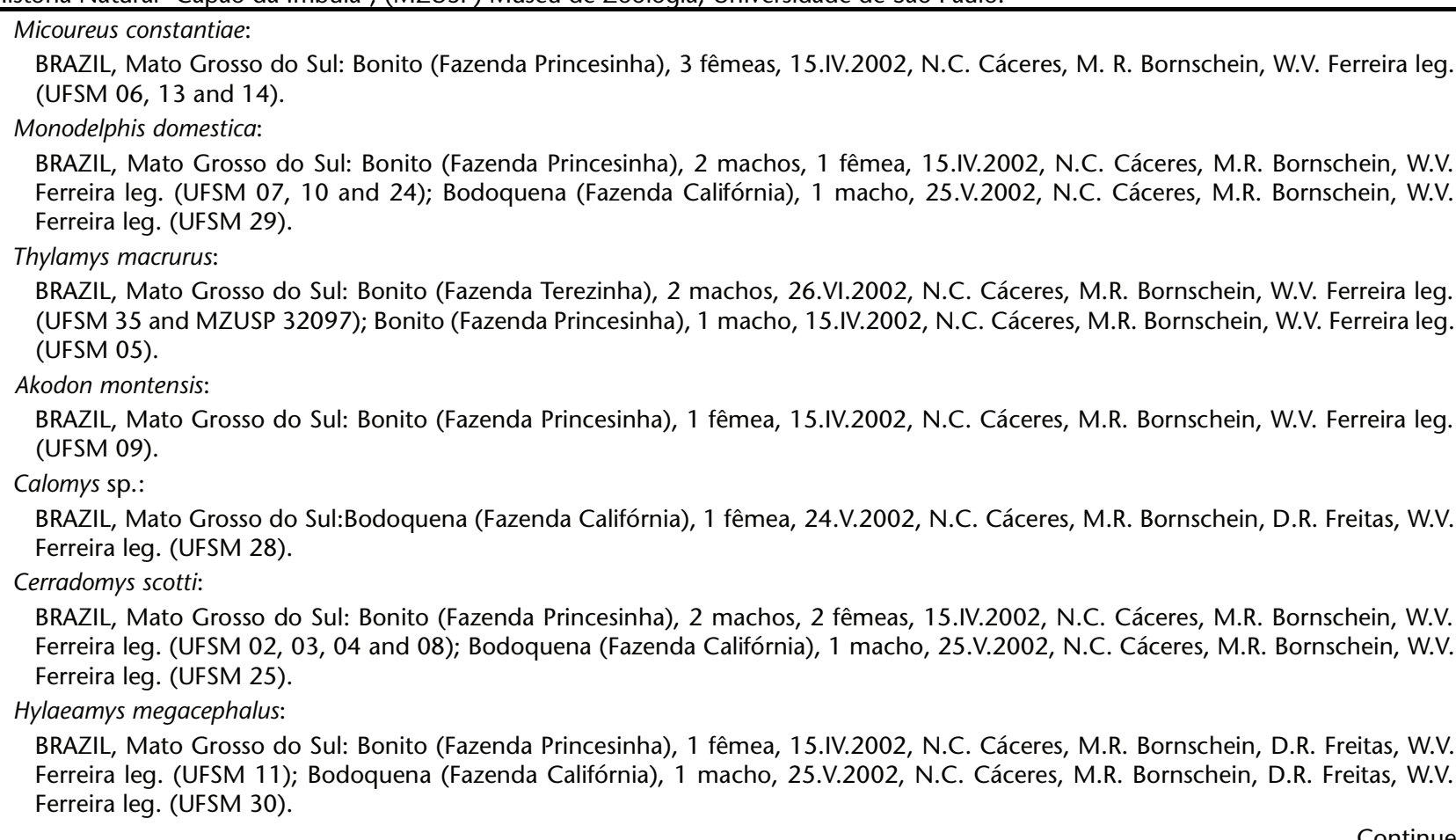


Appendix I. Continued.

Nectomys rattus:

BRAZIL, Mato Grosso do Sul: Bodoquena (Fazenda Califórnia), 1 macho, 24.V.2002, N.C. Cáceres, M.R. Bornschein, D.R. Freitas, W.V. Ferreira leg. (UFSM 27).

Oligoryzomys nigripes:

BRAZIL, Mato Grosso do Sul: Bonito (Fazenda Princesinha), 1 macho, 14.IV.2002, M.R. Bornschein, N.C. Cáceres, W.V. Ferreira leg. (UFSM 01).

Rattus rattus:

BRAZIL, Mato Grosso do Sul: Bonito (Fazenda Princesinha), 1 macho, 15.IV.2002, N.C. Cáceres, M.R. Bornschein, W.V. Ferreira leg. (UFSM 12).

Thrichomys pachyurus:

BRAZIL, Mato Grosso do Sul: Bonito (Fazenda Princesinha), 1 fêmea, 15.IV.2002, N.C. Cáceres, M.R. Bornschein, D.R. Freitas, W.V. Ferreira leg. (UFSM 15); Bodoquena (Fazenda Califórnia), 1 fêmea, 25.V.2002, N.C. Cáceres, M.R. Bornschein, D.R. Freitas, W.V. Ferreira leg. (UFSM 26).

Anoura caudifer:

BRAZIL, Mato Grosso do Sul: Bodoquena (Fazenda Califórnia), 1 macho, 22.V.2002, N.C. Cáceres, M.R. Bornschein leg. (UFSM 387). Artibeus jamaicensis:

BRAZIL, Mato Grosso do Sul: Bonito (Fazenda Princesinha), 1 fêmea, 11.IV.2002, N.C. Cáceres, M.R. Bornschein leg. (UFSM 392).

Carollia perspecillata:

BRAZIL, Mato Grosso do Sul: Bonito (Fazenda Princesinha), 1 macho, 1 fêmea, 11.IV.2002, N.C. Cáceres, M.R. Bornschein leg. (UFSM 71).

Desmodus rotundus:

BRAZIL, Mato Grosso do Sul: Bonito (Fazenda Princesinha), 1 macho, 1 fêmea, 11.IV.2002, N.C. Cáceres, M. R. Bornschein, W.V. Ferreira leg. (UFSM 144 and 145).

Eptesicus brasiliensis:

BRAZIL, Mato Grosso do Sul: Bonito (Fazenda Princesinha), 1 macho, 11.IV.2002, N.C. Cáceres leg. (UFSM 390).

Glossophaga soricina:

BRAZIL, Mato Grosso do Sul: Bonito (Fazenda Princesinha), 1 macho, 11.IV.2002, N.C. Cáceres, M.R. Bornschein leg. (UFSM 72).

Myotis sp.

BRAZIL, Mato Grosso do Sul: Bonito (Fazenda Princesinha), 11.IV.2002, N.C. Cáceres, M.R. Bornschein leg. (MHNCl number unknown).

Sturnira lilium:

BRAZIL, Mato Grosso do Sul: Bonito (Fazenda Princesinha), 1 fêmea, 11.IV.2002, N.C. Cáceres, M.R. Bornschein leg. (UFSM 391). 